\title{
Balance between intake and output of lead in normal individuals
}

\author{
JENNIFER A. THOMPSON \\ Department of Occupational Health, University of Manchester
}

\begin{abstract}
Thompson, J. A. (1970). Brit. J. industr. Med., 27, 189-194. Balance between intake and output of lead in normal individuals. The amount of lead ingested by a group of five 'normal' individuals for a number of consecutive days was determined; during the same period, the amount of lead which was excreted in faeces and urine was also determined and hence, by difference, the amount of lead retained in the body was calculated. The results showed a wide variation from day to day in the lead content of the food, with a range from $70 \mu \mathrm{g}$ to $750 \mu \mathrm{g}$; the average amount was $274 \mu \mathrm{g}$. The lead ingested was almost totally eliminated in faeces and urine; the amount of lead excreted daily ranged from $140 \mu \mathrm{g}$ to $625 \mu \mathrm{g}$ with an average of $264 \mu \mathrm{g}$. Only about $10 \mu \mathrm{g}$ on average per day, less than $4 \%$ of the average daily intake, was retained. At this rate of retention the lead accumulated would almost wholly account for the 'normal' body burden of lead found by tissue analysis.
\end{abstract}

Lead is found widely in animal and vegetable tissues, in water and in the atmosphere and is a normal constituent of the human diet. Intake and absorption of lead by the general population is therefore inevitable. Excessive absorption may result in systemic poisoning.

The present degree of exposure to lead of citizens of the United States has been termed 'chronic lead insult' and Patterson (1965) has suggested that the present rate of lead intake may already be sufficiently great to impair health. He maintains that the concentration of lead in the blood of 'normal' American citizens is approaching that at which symptoms of chronic poisoning may be expected and that the 'intellectual irritability' associated with lead poisoning might occur to a lesser but still significant extent in persons who are subject to chronic lead insult.

Lead is a normal constituent of the human body and only a small percentage of the total lead taken in by 'normal' individuals ${ }^{1}$ is retained (Kehoe, Thamann, and Cholak, 1933). The concentration of lead in the blood of 'normal' citizens residing in

'Normal' individuals refers to persons who have, or who have had, no unusual exposure to lead either in their occupation or accidentally. industrialized Western countries is similar to that of primitive peoples residing in non-industrialized areas of the world (Goldwater, 1967), and the concentration of lead in the blood of non-occupationally exposed individuals lies far below those concentrations at which symptoms of poisoning have been known to appear (Kehoe, 1961; Kubota, Lazar, and Losee, 1968). The reported instances of lead poisoning in 'normal' individuals usually arise from accidental over-exposure to lead and not from exposure in normal circumstances (Cantarow and Trumper, 1944; Moncrieff, Koumides, Clayton, Patrick, Renwick, and Roberts, 1964; Turner, Bamford, and Dodge, 1967; Bacon, Froome, Gent, Cooke, and Sowerby, 1967; Wilson, 1968; Power, Barnes, Nash, and Robinson, 1969).

The present investigation was carried out to determine the intake and output of lead over a given period of time by a group of 'normal' individuals and hence to establish the rate of retention.

\section{Method}

Procedure

Six volunteers collected duplicates of all meals consumed for periods of time which varied from subject to subject; 
the most was 28 days and the least was 12 days. The duplicates were saved for lead analysis. The volunteers also collected all faecal and urine samples during the same period and these, too, were analysed to determine the lead content. In this way, the intake and output of lead by each individual were measured and balanced and an estimate was made of the rate of retention of lead in the body. The intake of lead by inhalation and the output of lead in sweat and hair were not measured but are discussed later in the text.

\section{Subjects}

Many practical difficulties are encountered by volunteers while participating in an experiment of this nature. It is, for instance, virtually impossible to have a meal in a restaurant or to drink draught beer. Accepting drinks or sweets from friends becomes an embarrassment because one has to ask for an extra one for analysis, and one cannot go out for any length of time without carrying at least one polythene bottle.

The volunteers had to be reliable and diligent and willing to undertake, for a considerable time, a task which became very irksome. It was important that the volunteers labelled every item which they collected with the appropriate date and time, and that they maintained contact with the laboratory so that the collection of their samples of food and excreta could be adequately supervised.

It was decided that it would be better for a small number of reliable subjects to take part in the experiment rather than to attempt this delicate balance study on a large number of less willing and therefore less reliable people. In spite of the rigorous discipline which, of necessity, such an experiment imposes on its participants, six persons volunteered. The adequate supervision of one of the six subjects proved impossible and corresponding food and faecal samples were not obtained from him in some instances; the results from this subject have therefore been excluded.

The remaining five subjects, one of whom was female, were in the 21-30 year age-group and were resident in the Manchester area; the results show that this number of volunteers was sufficient to meet the objectives of the experiment.

\section{Collection of food and excreta}

Food and drink As far as possible without weighing, the duplicates matched the meals consumed. Each meal which was saved for lead analysis was collected in a leadfree polythene bag; the beverages were collected in leadfree polythene bottles. Each day was divided into four six-hourly periods, and food and beverages collected within each period were bulked together, made up to a known volume $(850 \mathrm{ml})$ with distilled water and macerated in a Waring blender to produce a homogeneous mixture. One hundred millilitres of the mixture was then stored in a lead-free polythene bottle until it could be analysed.

Faeces Each faecal sample was collected in a lead-free polythene bag and macerated to a volume of $500 \mathrm{ml}$ in lead-free nitric acid; approximately half of the mixture was stored in a lead-free bottle until it could be analysed. The error in the measurement of the food macerate $(850 \mathrm{ml})$ and faecal macerate $(500 \mathrm{ml})$ was approximately
$1 \%$. The collection of faeces began approximately one day after the start of food collection and terminated one day after the collection of food was ended. In this way, the time taken for food to pass through the alimentary canal was taken into account.

Urine Specimens of urine collected within each 24-hour period were bulked together and the total volume was measured. The specific gravity of each daily sample was measured using a urinometer calibrated in degrees from 1.000 to 1.060 . The creatinine concentration was determined by the alkaline picrate method of Owen, Iggo, Scandrett, and Stewart (1954). Approximately $100 \mathrm{ml}$ of each 24-hour sample was retained and stored for lead analysis. The remainder was discarded.

\section{Lead analysis}

Reagents Lead-free concentrated nitric acid; lead-free concentrated perchloric acid; standard lead solution, $100 \mu \mathrm{g} \mathrm{Pb} / \mathrm{ml}$ and $1 \mu \mathrm{g} \mathrm{Pb} / \mathrm{ml} ; 7 \mathrm{~N}$ hydrochloric acid (doubly distilled); potassium chloride solution, $10 \mathrm{~g} /$ litre; saturated solution of potassium hydrogen phthalate.

Apparatus Borosilicate glassware rendered lead-free by acid washing followed by thorough rinsing in tap water and distilled water; Davis A1660 Differential Cathode Ray Polarograph.

Procedure Known quantities of the stored samples were transferred to $100-\mathrm{ml}$ Erlenmeyer flasks; $12 \mathrm{ml}$ of the acid mixture $(250 \mathrm{ml}$ concentrated nitric acid; $100 \mathrm{ml}$ concentrated perchloric acid) and $1 \mathrm{ml}$ of the potassium chloride solution were added and the samples were ashed on an electric hotplate until only a white residue remained in the flask. The residue was dissolved in approximately $1 \mathrm{ml}$ of distilled water to which four drops of concentrated hydrochloric acid were added, and the solution was made up to a volume of $5 \mathrm{ml}$ with the potassium hydrogen phthalate solution so that the final $p \mathrm{H}$ was 2 to 3 . At this $p H$ there was no interference from other ions present in the solution. The solution was transferred to a polarograph cell and the concentration of lead was determined using the Cathode Ray Polarograph. Flasks containing only the added reagents served as blanks and all measurements were compared with standard solutions containing $1 \mu \mathrm{g} \mathrm{Pb} / \mathrm{ml}$ and $0 \cdot 1 \mu \mathrm{g} \mathrm{Pb} / \mathrm{ml}$ of electrolyte. The blanks usually contained 0.0 to $0.02 \mu \mathrm{g} \mathrm{Pb} / \mathrm{ml}$ of electrolyte; the ashed samples usually contained amounts of lead in the range 0.05 to $0.1 \mu \mathrm{g} \mathrm{Pb} / \mathrm{ml}$ of electrolyte. The mean percentage recovery of lead from all samples was $99 \%$.

\section{Results}

The total amounts of lead ingested and excreted, and the amount of lead retained (calculated by difference) by each of the five subjects during their respective experimental periods are shown in Table 1. They reveal that most of the lead ingested was subsequently excreted in the faeces and urine. On average, the four subjects $B$ to $E$ retained less than $5 \%$ of ingested lead; subject $\mathbf{A}$ excreted more lead than he ingested. 
Lead intake

A comparison between the individuals of the group shows a range in the average daily lead intake from $237 \mu \mathrm{g}$ to $306 \mu \mathrm{g}$ (Table 2). Subject C, the only female of the group, showed the lowest lead intake; this could probably be attributed to the smaller quantity of food consumed by this subject.

\section{Lead output}

Faeces The average daily faecal lead output of each subject ranged from $207 \mu \mathrm{g}$ to $271 \mu \mathrm{g}$ (Table 2). The frequency of bowel motions varied from individual to individual (Table 3). Subject B was the only person to provide at least one faecal sample each day. The least frequent samples were provided by subject $D(0.67$ sample/day).
Urine The average daily output of lead in urine ranged from $16 \mu \mathrm{g}$ to $30 \mu \mathrm{g}$ (Table 2). The urinary lead results have all been corrected to the average daily creatinine output for each individual (Table 3), because the creatinine output from day to day in any individual is relatively constant and independent of urinary volume (Bell, Davidson, and Scarborough, 1968); its measurement in any daily urine sample is a useful indicator as to whether every urine sample passed that day was in fact collected. Thus, by correcting every result obtained for the lead output to the creatinine output of each individual, a better measure of the actual amount of lead excreted was obtained.

In some instances, subjects failed to collect urine for a whole day; to allow for this in the total urinary

TABLE 1

Total Amounts of Lead Ingested, Excreted and Retained by Five Subjects

\begin{tabular}{|c|c|c|c|c|c|c|c|}
\hline Subject & No. of days & $\begin{array}{l}\text { Ingested } \mathrm{Pb} \\
(\mathrm{mg})\end{array}$ & $\begin{array}{l}\text { Faecal } P b \\
\quad(m g)\end{array}$ & $\begin{array}{l}\text { Urinary } P b \\
(m g)\end{array}$ & $\begin{array}{l}\text { Total output } \\
\quad(\mathrm{mg})\end{array}$ & $\begin{array}{c}\text { Amount } \\
\text { retained } \\
(m g)\end{array}$ & $\begin{array}{l}\text { Percentage } \\
\text { retention }\end{array}$ \\
\hline $\begin{array}{l}\text { A } \\
\text { B } \\
\mathbf{C} \\
\mathbf{D} \\
\mathbf{E}\end{array}$ & $\begin{array}{l}28 \\
25 \\
28 \\
24 \\
12\end{array}$ & $\begin{array}{l}7 \cdot 765 \\
7 \cdot 652 \\
6 \cdot 648 \\
6 \cdot 509 \\
3 \cdot 522\end{array}$ & $\begin{array}{l}7 \cdot 119 \\
6 \cdot 782 \\
5 \cdot 787 \\
5 \cdot 121 \\
3 \cdot 243\end{array}$ & $\begin{array}{l}0.841 \\
0.573 \\
0.647 \\
0.591 \\
0.198\end{array}$ & $\begin{array}{l}7 \cdot 960 \\
7 \cdot 355 \\
6 \cdot 434 \\
5 \cdot 712 \\
3 \cdot 441\end{array}$ & $\begin{array}{r}-0.195 \\
0.297 \\
0.214 \\
0.797 \\
0.081\end{array}$ & $\begin{array}{r}-2 \cdot 5 \\
3 \cdot 9 \\
3 \cdot 2 \\
12 \cdot 2 \\
0 \cdot 2\end{array}$ \\
\hline
\end{tabular}

TABLE 2

Average Daily Amounts of Lead Ingested, Excreted and Retained by Five Subjects

\begin{tabular}{c|c|c|c|c|c}
\hline Subject & $\begin{array}{c}\text { Food intake } \\
(\mu g)\end{array}$ & $\begin{array}{c}\text { Faecal output } \\
(\mu g)\end{array}$ & $\begin{array}{c}\text { Urinary output } \\
\text { (corrected for creatinine output) } \\
(\mu g)\end{array}$ & $\begin{array}{c}\text { Total output } \\
(\mu g)\end{array}$ & $\begin{array}{c}\text { Retained } \\
(\mu g)\end{array}$ \\
\hline A & $277 \cdot 3$ & $254 \cdot 3$ & $30 \cdot 0$ & $284 \cdot 3$ & $-7 \cdot 0$ \\
B & $306 \cdot 1$ & $271 \cdot 3$ & 22.9 & $294 \cdot 2$ & $11 \cdot 9$ \\
C & $237 \cdot 4$ & $206 \cdot 7$ & $23 \cdot 1$ & $229 \cdot 8$ & $7 \cdot 6$ \\
D & $271 \cdot 2$ & $213 \cdot 4$ & $24 \cdot 6$ & $238 \cdot 0$ & 3.2 \\
E & $293 \cdot 5$ & $270 \cdot 3$ & $16 \cdot 5$ & $286 \cdot 2$ & $6 \cdot 3$ \\
mean of all & $274 \cdot 3$ & $239 \cdot 8$ & $24 \cdot 4$ & $264 \cdot 1$ & $10 \cdot 2$ \\
\hline
\end{tabular}

TABLE 3

Biological Function Data

\begin{tabular}{|c|c|c|c|c|}
\hline \multirow[b]{2}{*}{ Subject } & \multicolumn{4}{|c|}{ Average daily } \\
\hline & $\begin{array}{c}\text { Faecal samples } \\
(\text { No. })\end{array}$ & $\begin{array}{l}\text { Urine vol. } \\
\quad(\mathrm{ml})\end{array}$ & Specific gravity & $\begin{array}{c}\text { Creatine output } \\
(g)\end{array}$ \\
\hline $\begin{array}{l}\text { A } \\
\text { B } \\
\text { C } \\
\text { D } \\
\text { E }\end{array}$ & $\begin{array}{l}0.71 \\
1.08 \\
0.86 \\
0.67 \\
0.75\end{array}$ & $\begin{array}{r}1283 \\
888 \\
830 \\
743 \\
928\end{array}$ & $\begin{array}{l}1 \cdot 015 \\
1 \cdot 022 \\
1 \cdot 017 \\
1 \cdot 023 \\
1.023\end{array}$ & $\begin{array}{l}1.390 \\
1.386 \\
1.007 \\
1.042 \\
1.415\end{array}$ \\
\hline
\end{tabular}


lead output figure for each subject, the appropriate number of average daily values have been added.

\section{Distribution of amounts of lead in food, faeces and urine}

Eighty-two per cent of the daily food samples and $78 \%$ of the faecal samples contained amounts of lead in the range 100 to $399 \mu \mathrm{g}$ (Table 4). Of the daily urine samples $89 \%$ contained amounts of lead in the range 10 to $39 \mu \mathrm{g}$.

\section{Lead balance}

The patterns of the intake and the total output of lead of the four subjects who carried out the experiment for at least 24 days are shown in the Figure. The values in the lead intake pattern represent the lead content of the daily food samples; although the values in the distribution of lead output represent the lead content of samples which were obtained at irregular intervals rather than each day, it is apparent that the pattern of lead excretion follows that of the ingested lead. (No adjustment has been made for the time lag in the intake and output as it is not constant for the whole period.)

It seems that individuals have a capacity for eliminating lead and that a very high proportion of ingested lead is excreted. The elimination is affected not only at the lower levels of lead intake but also at the higher levels in 'normal' exposure.

\section{Discussion}

The average daily amount of lead in the food of the subjects, none of whom had any occupational exposure to lead, was $274 \mu \mathrm{g}$. This is less than the $400 \mu \mathrm{g}$ stated by Patterson (1965) to be the average amount of lead ingested daily by citizens of the United States, but it is similar to the figures of $300 \mu \mathrm{g}$ given by Kehoe (1961). Monier-Williams in 1938 estimated that British citizens at that time ingested $500 \mu \mathrm{g}$ of lead daily, and so it seems possible

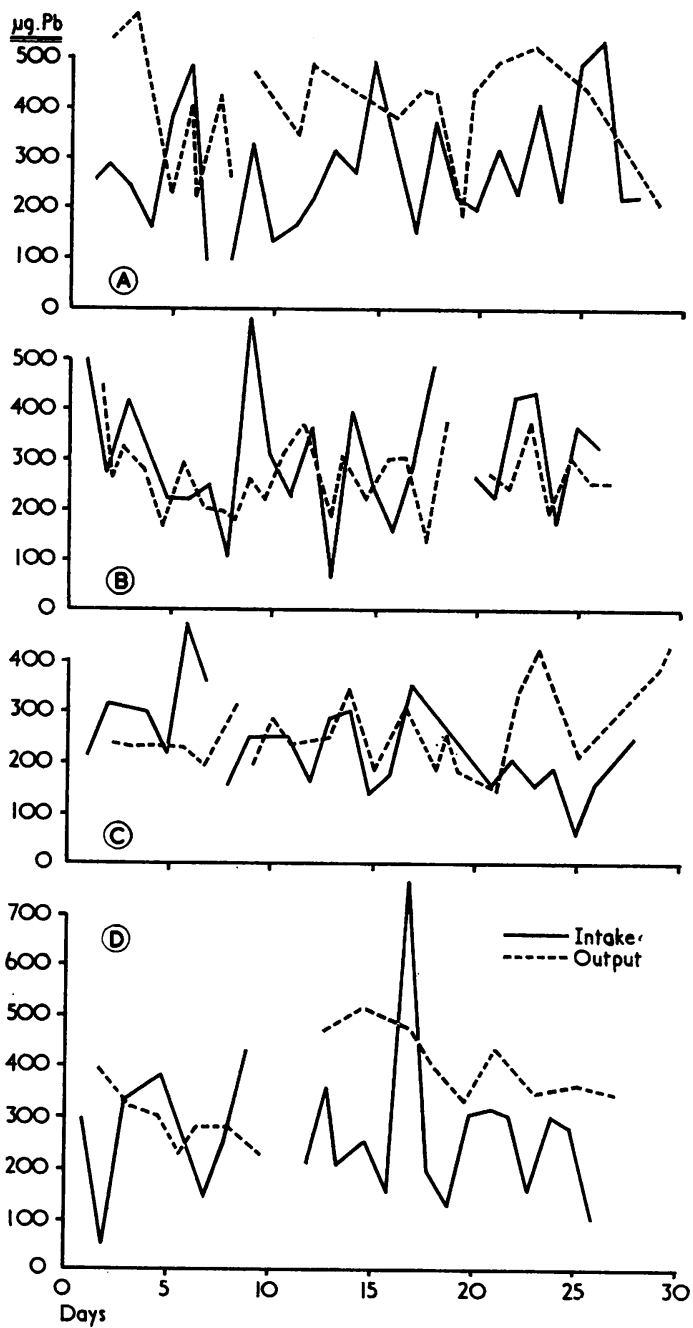

FIGURE. The pattern of lead intake and output.

TABLE 4

Distribution of Lead in Food, Faeces and URINe

\begin{tabular}{|c|c|c|c|c|c|c|c|}
\hline \multirow{2}{*}{$\begin{array}{c}\text { Range } \\
(\mu g P b)\end{array}$} & \multicolumn{2}{|c|}{ Food } & \multicolumn{2}{|c|}{ Faeces } & \multirow{2}{*}{$\begin{array}{c}\text { Range } \\
(\mu g P b)\end{array}$} & \multicolumn{2}{|c|}{ Urine } \\
\hline & No. & $\%$ & No. & $\%$ & & No. & $\%$ \\
\hline $\begin{array}{r}0-99 \\
100-199 \\
200-299 \\
300-399 \\
400-499 \\
500-599 \\
600-699 \\
700-799\end{array}$ & $\begin{array}{r}6 \\
22 \\
41 \\
33 \\
11 \\
3 \\
0 \\
1\end{array}$ & $\begin{array}{r}5.1 \\
18.8 \\
35.0 \\
28 \cdot 2 \\
9.4 \\
2.6 \\
0.0 \\
0.9\end{array}$ & $\begin{array}{r}0 \\
23 \\
34 \\
18 \\
18 \\
2 \\
1 \\
0\end{array}$ & $\begin{array}{c}0 \\
24 \cdot 0 \\
35 \cdot 4 \\
18 \cdot 75 \\
18 \cdot 75 \\
2 \cdot 1 \\
1 \cdot 0 \\
0\end{array}$ & $\begin{array}{r}0-9 \\
10-19 \\
20-29 \\
30-39 \\
40-49 \\
50-59 \\
60-69 \\
70-79\end{array}$ & $\begin{array}{r}5 \\
37 \\
39 \\
19 \\
4 \\
2 \\
1 \\
0\end{array}$ & $\begin{array}{r}4 \cdot 7 \\
34 \cdot 6 \\
36 \cdot 4 \\
17 \cdot 8 \\
3.7 \\
1.9 \\
0.9 \\
0\end{array}$ \\
\hline Total & 117 & $100 \cdot 0$ & 96 & $100 \cdot 0$ & & 107 & $100 \cdot 0$ \\
\hline
\end{tabular}


that there has been a reduction in the amount of lead in food in this country since 1938.

\section{Lead retention}

The average quantity of lead retained daily by all subjects was $10 \mu \mathrm{g}$ with a range of $6 \mu \mathrm{g}$ to $33 \mu \mathrm{g}$. Subject A excreted more lead than he ingested (Table 2). He also showed the greatest daily output of lead in urine $(30 \mu \mathrm{g})$; the excess lead excretion by this subject could be due to a greater exposure to atmospheric lead than that experienced by the other subjects but this cannot be proved as no measurements were made of the subjects' intake of lead by inhalation.

Subject D retained, on average, the greatest quantity of lead daily; this may be associated with the relatively infrequent faecal motions of this subject ( 0.67 sample per day) for it was noted by Kehoe (1961) that 'a greater degree of absorption of lead occurred when the retention of the contents of the alimentary tract was prolonged'.

An approximate balance between ingested lead and lead output has been shown to exist, although neither the lead taken in by inhalation nor that excreted in sweat and hair has been taken into account.

An estimate based upon the mean annual concentration of lead in the atmosphere of Fleet Street $\left(3.2 \mu \mathrm{g} / \mathrm{m}^{3}\right.$; Waller, Commins, and Lawther, 1965), shows that the subjects may have inhaled about $30 \mu \mathrm{g}$ of lead each day, of which 25 to $50 \%$ may have been absorbed (Goldsmith and Hexter, 1967). Assuming that the concentration of lead in sweat is approximately the same as that in urine (Kehoe, 1961), the subjects probably excreted about $12 \mu \mathrm{g}$ of lead per day in sweat. The mean concentration of lead in human hair was found to be about $18 \mu \mathrm{g} / \mathrm{g}$ (Schroeder and Tipton, 1968) and it is possible that several microgrammes of lead may be excreted daily via this route. It seems from these figures that the amount of lead absorbed daily from the respiratory tract approximates to that excreted daily in sweat and hair; the amounts are of the same order as the difference between the ingested lead and that excreted in faeces and urine and are much smaller than the total intake and output values.

The total body burden of lead in non-occupationally exposed individuals has been estimated by other authors after post-mortem analyses of the various tissues of the body. Kehoe (1961) placed the human body burden of 'normal' individuals at between 100 and $400 \mathrm{mg}$ but failed to give the length of time for such an amount of lead to accumulate. Schroeder and Tipton (1968) estimated that in 50 years the amount of lead retained in the human body could range from 50 to $200 \mathrm{mg}$.

Barry and Mossman (1970) found that the total body burden of lead in men aged over 50 years ranged from $180 \mathrm{mg}$ to $352 \mathrm{mg}$ with a mean of $222 \mathrm{mg}$. If it is assumed that this mean body burden of lead was accumulated gradually day by day for an average of 60 years, the amount of lead retained daily would have been approximately $10 \mu \mathrm{g}$, which is very close to the average amount of lead which was retained daily by the individuals in this investigation.

It appears therefore that a daily retention of lead could account for the presence of lead in human tissues but it must be emphasized that the daily retention is normally less than $10 \%$ of the total lead intake and that therefore more than $90 \%$ is effectively eliminated from the body.

\section{Conclusions}

The results from this study suggest that the concentration of lead in food has not increased over the past 30 years, that the ingested lead is almost completely eliminated in faeces and urine and that the amount of lead retained daily could, on accumulation, almost wholly account for the body burden of lead calculated from tissue analysis.

I wish to thank Professor T. S. Scott and Dr. M. K. B. Molyneux for advice and encouragement, Mr. D. K. Taylor for technical assistance, and the subjects for their participation in the experiment. The Associated Octel Company Ltd., who provided the financial support, are gratefully acknowledged.

This work formed part of a thesis submitted for the degree of M.Sc. in the University of Manchester.

\section{References}

Bacon, A. P. C., Froome, K., Gent, A. E., Cooke, T. K., and Sowerby, P. (1967). Lead poisoning from drinking soft water. Lancet, 1 , 264-266.

Barry, P. S. I., and Mossman, ग. B. (1970). Lead concentrations in human tissues. Brit. J. industr. Med., 27, 339-351.

Bell, G. H., Davidson, J. N., and Scarborough, H. (1968). Textbook of Physiology and Biochemistry. 7th ed., p. 434. Livingstone, Edinburgh and London.

Cantarow, A., and Trumper, M. (1944). Lead Poisoning, pp. 199-200. Williams and Wilkins, Baltimore.

Goldsmith, J. R., and Hexter, A. C. (1967). Respiratory exposure to lead: epidemiological and experimental dose-response relationships. Science, 158, 132-134.

Goldwater, L. J. (1967). 'Normal' concentrations of metals in urine and blood. W.H.O. Chron., 21, 191-192.

Kehoe, R. A. (1961). The metabolism of lead in man in health and disease. The Harben lectures, 1960. Reprinted from J. roy. Inst. publ. Hlth., 24, 81-96, 101-120, 129-143, and 177-203.

, Thamann, F., and Cholak, J. (1933). On the normal absorption and excretion of lead. $J$. industr. Hyg., 15, 257-272.

Kubota, J., Lazar, V. A., and Losee, F. (1968). Copper, zinc, cadmium and lead in human blood from 19 locations in the United States. Arch. environm. Hlth, 16, 788-793.

Moncrieff, A. A., Koumides, O. P., Clayton, B. E., Patrick, A. D. Renwick, A. G. C., and Roberts, G. E. (1964). Lead poisoning in children. Arch. Dis. Childh, 39, 1-13.

Monier-Williams, G. W. (1938). Lead in Food. Ministry of Health Reports on Public Health and Medical Subjects. No. 88.

Owen, J. A., Iggo, B., Scandrett, F. J., and Stewart, C. P. (1954). The determination of creatinine in plasma or serum, and in urine; a critical examination. Biochem. J., 58, 426-437.

Patterson, C. C. (1965). Contaminated and natural lead environments of man. Arch. environm. Hith, 11, 344-360. 
Power, J. G. P., Barnes, R. M., Nash, W. N. C., and Robinson, J. D. (1969). Lead poisoning in Gurkha soldiers in Hong Kong. Brit. med. J., 3, 336-337.

Schroeder, H. A., and Tipton, I. H. (1968). The human body burden of lead. Arch. environm. Hith, 17, 965-978.

Turner, W., Bamford, F. N., and Dodge, J. S. (1967). Lead poisoning at Bradford. Brit. med. J., 3, 56.
Waller, R. E., Commins, B. T., and Lawther, P. J. (1965). Air pollution in a city street. Brit. J. industr. Med., 22, $128-138$.

Wilson, A. T. (1968). Acute vertigo and the lead content of food and drink. Practitioner, 200, 282-285.

Received for publication June 2, 1970.

\section{The January (1971) Issue}

Decompression sickness and aseptic necrosis of bone Report of DeCompkession Sickness Panel, Medical RESEARCH COUNCIL

The doctor in the Industrial Revolution Michael E. Rose

Hazards of deep-sea fishing R. S. F. Schilling

Absence from work in relation to length and distribution of shift hours J. WALKER AND GWYNNETH DE LA MARE

The selection of juvenile entrants to mining J. S. McLinTock

An assessment of the laboratory tests used to monitor the exposure of lead workers BirgitTA HAEGERARONSEN

Epidemiology of mesothelioma on Walcheren Island J. STUMPHIUS

Paraquat in the rabbit COOLey Butler II AND Jerome KLeINERMAN

Poly(vinylpyridine oxides) in pneumoconiosis research P. F. HolT

Chronic manganese poisoning in the dry battery industry A. M. Emara, S. H. El-Ghawabi, O. I. MadKour, AND G. H. EL-SAMRA

Vibration syndrome in Forestry Commission chain saw operators W. TAYLOR, J. PeARson, R. L. Kell, AND G. D. KeIGHLEY

Notes and miscellanea

Vibration syndrome R. I. MCCALlum

International classification of radiographs of pneumoconioses $\quad$ P. C. ELMES

Gas chromatographic determination of phosgene and dichloroacetylene in air R. JELTES, E. BURGHARDT, AND J. BREMAN

Book reviews

A number of copies are still available and may be obtained from the Publishing Manager, British Medical Association, Tavistock Square, London WC1H 9JR price $£ 1.25$ ( $£ 1.5$ in countries overseas; U.S.A. $\$ 3 \cdot 60$ ). 